\title{
ERRATA DO ARTIGO: Hibridación y diferenciación discursiva entre kleinismo y lacanismo (Uruguay, 1955-1982)
}

Rev. Latinoam. Psicopat. Fund., São Paulo, 22(4), 884-908, dez. 2019

Nas páginas 884 e 908

Onde se lia

Gonzalo Grau Pérez*2

Gonzalo Grau Pérez

Leia-se

Gonzalo Grau-Pérez*2

Gonzalo Grau-Pérez

Editora: Profa. Dra. Ana Maria Rudge.

This is an open-access article, which permits unrestricted use, distribution, and reproduction in any medium for non-commercial purposes provided the original authors and sources are credited. 